\title{
LAYANAN TANPA TURUN SERPONG
}

\author{
Peter $^{1)}$, Martin Halim²) \\ 1)Program Studi S1 Arsitektur, Fakultas Teknik, Universitas Tarumanagara, Peterlay524@gmail.com \\ 2) Program Studi S1 Arsitektur, Fakultas Teknik, Universitas Tarumanagara, Martinhalim90@gmail.com
}

\begin{abstract}
Abstrak
Menurut Martin Heidegger dwelling adalah sebuah aktivitas individu di dalam bumi ini. Aktivitas manusia yang paling penting adalah berbelanja dimana berfungsi untuk memenuhi kebutuhan. Pada awal tahun 2020 COVID-19 terjadi sehingga pemerintah mengeluarkan kebijakan untuk melakukan social distancing. Kebijakan tersebut merusak kegiatan $d$ welling yang terjadi. Secara umum setiap individu harus menjaga jarak namun hal tersebut sering dilanggar. Kendaraan bermotor dapat menyelesaikan masalah tersebut dimana setiap individu dipaksa membuat jarak. Tapak dipilih berdasarkan Jalan Raya Serpong, dimana jalan tersebut menghubungi Tanggerang Selatan dan Bogor. Tapak terpilih dekat dengan entrance Alam Sutera karena peruntukkan lebih dominan hunian. Pengguna jalan pada tapak lebih banyak menggunakan kendaraan bermotor sedangkan pejalan kaki sangat minim. Kurangnya pejalan kaki diakibatkan fasilitas umum yang kurang baik. Setelah pemerintah mengeluarkan kebijakan untuk social distancing masyarakat lebih senang menggunakan fasilitas drive-thru untuk berbelanja. Sehingga dalam rancangan menggunakan konsep layanan tanpa turun. Layanan tanpa turun disini berbicara 3 hal yaitu drive-in, drive-thru, dan pickup point. Dimana program utama berupa dine-in dan drive-thru supermarket. Dengan adanya konsep layanan tanpa turun aktivitas dwelling masih dapat berjalan. Konsep tersebut juga tidak terikat dengan waktu sehingga tidak ada masa kadaluarsa karena kendaraan akan selalu ada di masa depan. Proyek tersebut bertujuan untuk mempertahankan gaya hidup yang ada.
\end{abstract}

Kata kunci: Dwelling; Gaya Hidup; Kendaraan Bermotor; Layanan tanpa turun; Social Distancing.

\begin{abstract}
According to Martin Heidegger, dwelling is an individual activity on this earth. Shopping is one of important activity for surviving. In early 2020, COVID-19 occurred so that the government issued a policy to carry out social distancing. The policy damages the dwelling activities that occur. In general, every individual must maintain a distance but this is often violated. Vehicles can solve this problem where each individual is forced to make a distance. The site was chosen based on Jalan Raya Serpong, where it connects South Tanggerang and Bogor. The site was chosen close to the entrance of Alam Sutera because the designation was predominantly residential. More road users on the site use vehicles while pedestrians are minimal. The lack of pedestrians is due to poor public facilities. After the government issued a policy for social distancing, the public preferred to use the drive-thru facility for shopping. So that the design uses the concept of service without going down. The service without getting down here talks about 3 things, namely drive-in, drive-thru, and pickup point. Where the main programs are dine-in and drive-thru supermarkets. With the concept dwelling activity can still run. The concept is also not bound by time so that there is no expiration date because vehicles will always exist in the future. The project aims to maintain the existing lifestyle.
\end{abstract}

Keywords: Dwelling; Lifestyle; Service without going down; Social Distancing; Transportation. 


\section{PENDAHULUAN}

\section{Latar Belakang}

Dwelling kata ini sering muncul dalam kalimat "Human Dwelling on earth" dimana berbicara bagaimana manusia bertahan hidup. Berburu merupakan aktivitas utama karena berfungsi untuk memenuhi kebutuhan. Seiring berjalannya waktu kegiatan berburu tergantikan oleh berbelanja. Namun pada tahun 2020 terjadi penyebaran virus COVID-19 dimana membuat pemerintah membuat keputusan untuk melakukan social distancing. Social distancing menyebabkan munculnya perubahan dalam beberapa aktivitas. Dalam berbelanja makanan setiap individu lebih memilih untuk menggunakan layanan drive-thru. Sedangkan layanan makan ditempat jarang digunakan karena social distancing.

\section{Rumusan Permasalahan}

Pada survey ditemukan permasalahan yang terjadi pada Kawasan Alam Sutera akibat oleh social distancing. Permasalahan yang terjadi dimana kurangnya tempat bagi masyarakat untuk bersosialisasi secara aman. Permasalahan ini diakibatkan oleh kurang siapnya setiap tempat komersial untuk menghadapi masalah social distancing yang terjadi. Sehingga pihak pemerintah mengeluarkan kebijakan dimana setiap tempat komersial harus ditutup.

\section{Tujuan}

Atas dasar masalah yang ada tersebut, proyek yang ada memiliki tujuan untuk menciptakan sebuah proyek yang reselient. Reselient ini berbicara mampu beradaptasi dengan keadaan yang ada yaitu dalam hal ini social distancing. Proyek yang dapat berjalan saat adanya social distancing ataupun tidak adanya social distancing. Sehingga lifestyle yang ada dapat dipertahankan dan masyarakat dapat melakukan kegiatan dwelling dengan nyaman.

\section{KAJIAN LITERATUR}

Dalam melakukan perancangan penulis berorientasi pada teori yang sudah ada untuk memahami lebih dalam makna dari sebuah dwelling. Teori yang diambil adalah fourfold dan social menurut Martin Heidegger dijadikan sebagai dasar dalam mendesain. Teori perbedaan $d$ welling dan home dijadikan salah satu teori yang memperkuat makna dari dwelling. Studi teori ini dilakukan untuk mengetahui masalah dwelling yang terjadi dalam Indonesia. Sehingga masalah tersebut dapat diselesaikan dengan rancangan yang akan dibuat.

\section{Fourfold}

Menurut Martin Heidegger dwelling terjadi karena 4 hal yaitu: earth, sky, divinity, dan mortals. 4 hal tersebut memiliki makna secara arsitektural, yaitu:

- Earth merupakan space yang ada

- Sky merupakan kualitas ruang yang ada

- Divinity sesuatu yang hidup antara earth dan sky

- Mortals berbicara tentang sosial

Martin Heidegger juga menyebutkan tentang draw dan spiritual. Dimana draw ini memiliki makna constructuting yang berarti membuat sesuatu yang belum ada. Sedangkan spiritual ini memiliki makna cultivating yang berarti mengembangkan sesuatu. Dapat dikatakan bahwa sky dan earth merupakan bagian dari draw. Sedangkan divinity dan mortal merupakan bagian dari spiritual.

\section{Social}

Social berbicara tentang manusia, hewan dan tumbuhan. Dimana manusia ada karena 3 hal yang sibut dengan vita activa. Vita activa ini berbicara tentang work, labor, dan action. Work berbicara tentang aktivitas manusia dengan sesuatu. Sedangkan labor berbicara tentang 
mekanisme dalam tubuh setiap individu. Action berbicara tentang keberagaman dalam hal seperti ide, sosial, hubungan, dan lain-lain.

\section{Perbedaan Dwelling dan Home}

Menurut The Second UN Confrence on Human Settlement in 1996 dwelling memiliki kriteria seperti:"A proper shelter is not only the existence of a roof over people's head. A proper shelter means proper comfort, a proper space, suitable physical approach and security, ownership security, structural stability, lighting, ventilation, proper heating system, primary substructure such as water, health-care and education, garbage evacuation, proper environmental elements, proper health factors, accessible to work place and accommodations and all these factors must be provided according to financial status of people". Melalui hal ini dapat disimpulkan bahwa makna dwelling lebih dari sekedar ruang. Bagian terpenting pada dwelling adalah memenuhi kebutuhan manusia seperti menyiapkan makanan, beristirahat,dll. Dapat disimpulkan bahwa concept of dwelling is not a residential unit but the whole residence of living.

\section{METODE}

Dalam melakukan perancangan penulis melakukan pengumpulan data berupa kondisi eksisiting lingkungan dan juga fenomena yang terjadi dalam masyarakat melalui penerapan metode pengumpulan data baik primer maupun sekunder yang kemudian akan dianalisis baik dari segi tapak, fungsi pada bangunan, pengguna, ruang dan juga bentuk rancangan melalui proses metode analisis.

\section{Pengumpulan Data}

a. Pengumpulan data primer

Data primer dikumpulkan pada hari Sabtu 15 Agustus 2020 dengan waktu 08.00, 13.00, dan 20.00. Pada survey ini dilakukan pengamatan secara individual dan juga melakukan wawancara terhadap pekerja yang sedang istirahat.

b. Pengumpulan data sekunder

Dalam penulisan ini data sekunder didapat dari Peraturan Daerah Kota Tanggerang Selatan. Dimana tertulis dalam Peraturan Daerah Kota Tanggerang Selatan Nomor 15 tahun 2011 tentang Rencana Tata Ruang Wilayah kota Tanggerang Selatan. Dasar penyusunan Rencana Tata Ruang Wilayah Kota Tanggerang Selatan mengacu pada UU No.26 Tahun 2007 tentang Penataan Ruang dan Peraturan Pemerintah No. 26 Tahun 2008 tentang Rencana Tata Ruang Wilayah nasional.

c. Studi preseden

Untuk mengetahui fungsi-fungsi yang diperlukan dalam mendesain Layanan Tanpa Turun Serpong

d. Studi literatur

Untuk mengetahui makna dwelling dan mencari tahu masalah yang sedang terjadi saat ini

\section{Pengolahan Data}

Berbagai macam data yang sudah dikumpulkan dan distudi untuk mendapatkan dasar dari perancangan proyek Layanan Tanpa Turun.

\section{Metode Analisis}

Analisis merupakan proses pengamatan yang berdasarkan kriteria tertentu sehingga dapat melahirkan solusi yang bersifat ilmiah. Beberapa analisis yang dilakukan dalam perancangan arsitektur, diantaranya;

a. Analisis tapak, yang membahas mengenai masalah dan kondisi eksisting tapak.

b. Analisis fungsi bangunan, membahas baik fungsi utama dan penunjang bangunan.

c. Analisis sirkulasi, yang membahas sirkulasi pengguna dalam bangunan 
d. Analisis bentuk, yang membahas bentuk fisik bangunan dengan konsep yang terpilih

e. Analisis konsep penerapan pada desain

\section{DISKUSI DAN HASIL}

Perancangan bangunan ini terbagi menjadi beberapa konsep hasil dari analisis yang dilakukan meliputi analisis tapak, analisis fungsi bangunan, analisis sirkulasi, analisis ruang, analisis MEP, dan analisis bentuk.

\section{Analisis Tapak}

Tapak yang diambil terletak di samping jalan Serpong Raya, jalan tersebut menghubungi Tanggerang Selatan dan Bogor. Tapak memiliki bentuk trapesium dengan luas 1 ha. Untuk peraturan bangunannya KDB sebesar 70, KLB 8, KDH 10, dan ketinggian bangunan 4 lapis. Data ini didapat dari peraturan daerah kota Tanggerang Selatan nomor 15 tahun 2011 pasal 81.

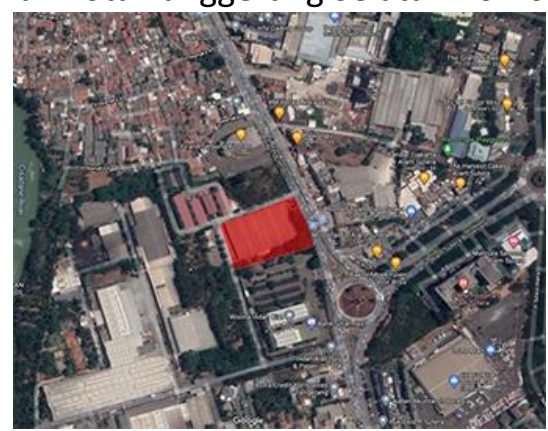

Gambar 1. Peta lokasi tapak dan kondisi eksisting Sumber: Google maps

\section{Analisa kepadatan}

Kepadatan terjadi saat makan siang kearah Alam Sutera. Menurut hasil wawancara jalan Serpong Raya semakin sepi akibat new normal. Namun jalan Serpong Raya tidak pernah mengalami kemacetan parah. Hanya padat akibat adanya lampu merah yang cukup lama.
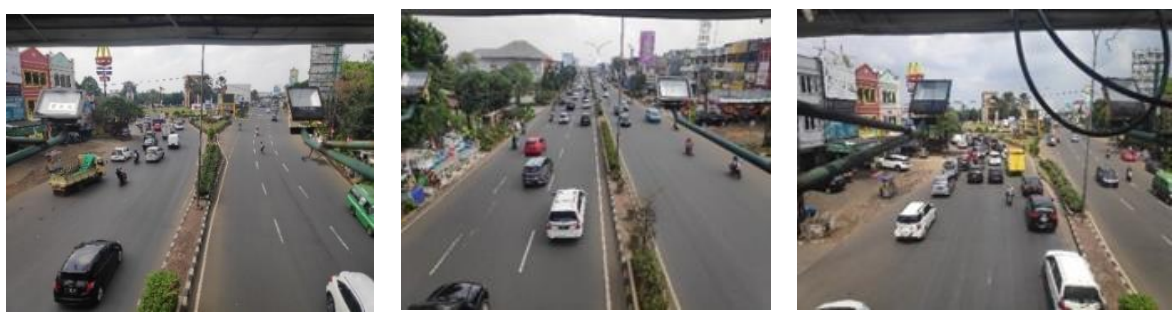

Gambar 2. Jam 09.00 foto ke arah Alam Sutera (kiri), Jam 09.00 foto ke arah Serpong (tengah), Jam 13.00 foto ke arah Alam Sutera (kanan) Sumber: Penulis, 2020
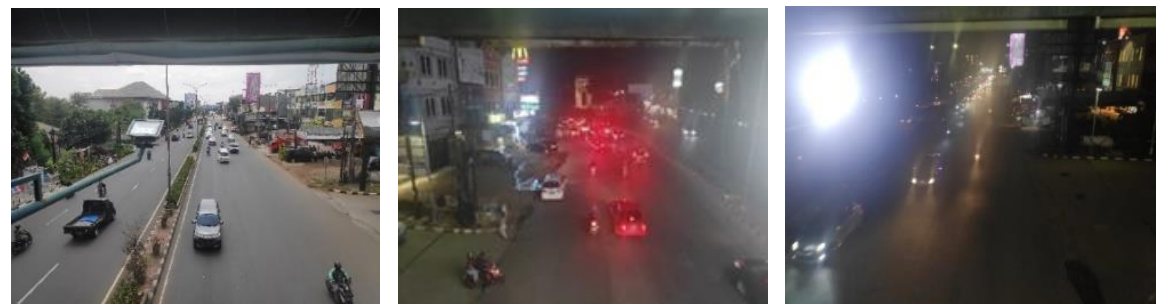

Gambar 3. Jam 13.00 foto ke arah Serpong (kiri), Jam 19.00 foto ke arah Alam Sutera (tengah), Jam 19.00 foto ke arah Serpong (kanan)

Sumber: Penulis, 2020 


\section{Analisa Program}

Berikut merupakan data setiap fastfood dekat jalan Serpong Raya - Alam Sutera. Data tersebut diambil pada hari Sabtu 15 Agustus 2020 dengan jam09.00, 13.00, dan 19.00 . Menurut hasil pengamatan dan wawancara satpam fastfood 1 dan fastfood 2. Sebelum karantina tempat makan tersebut cukup ramai dengan pengunjung. Setelah berjalannya new normal pengunjung lebih banyak melakukan take away.
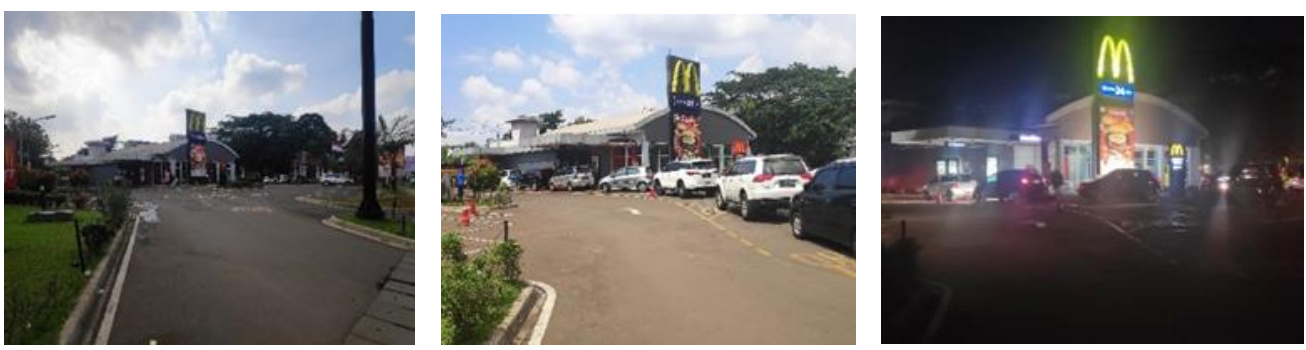

Gambar 4. Keadaan drive-thru fastfood 1 pada 09.00 (kiri); keadaan drive-thru fastfood 1 pada 13.00 (tengah); Keadaan drive-thru fastfood 1 pada 19.00 (kanan)

Sumber: Penulis, 2020
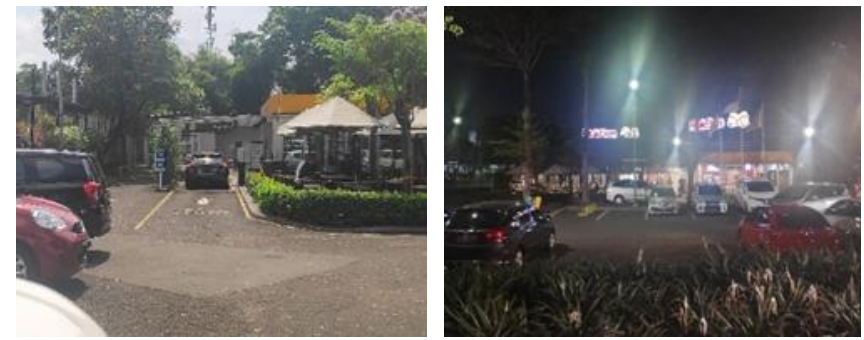

Gambar 5. Keadaan drive-thru fastfood 2 pada 13.00 (kiri);

Keadaan drive-thru fastfood 2 pada 19.00 (kanan)

Sumber: Penulis, 2020

Analisa Fasilitas Umum

Akses menuju tangga penyebrangan dihalangi oleh PKL (gambar 13) Akses menuju tangga penyebrangan dihalangi oleh kolom (gambar 6)
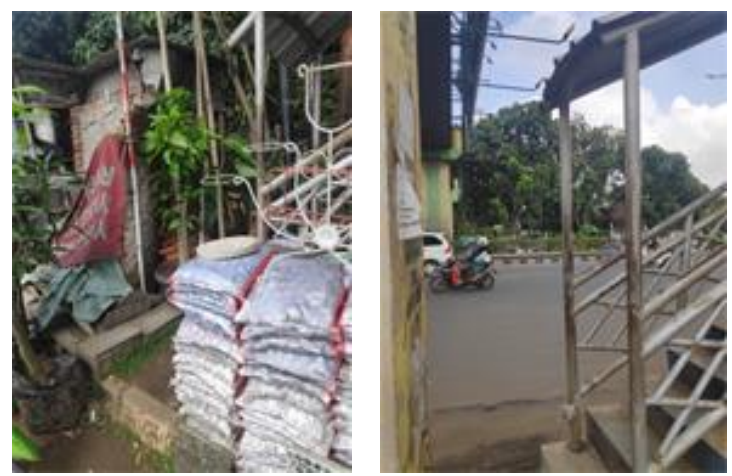

Gambar 6. Akses masuk menuju jembatan penyebrangan (kiri), Akses masuk menuju jembatan penyebrangan (kanan) Sumber: Penulis, 2020

\section{Analisis Fungsi}


Rancangan program pada layanan tanpa turun dibagi menjadi 4 yaitu area drive-in, drive-thru, pickup point, dan servis. Dimana program utama merupakan program dine-in dan supermarket dimana berfungsi untuk mempertahankan lifestyle yang ada akibat social distancing.

\section{Area Drive-in}

Area drive-in menyediakan tempat makan sekaligus tempat charging mobil. Dimana charging station berfungsi menjadi anchor. Sehingga pada area drive-in menggunakan konsep charging + eat. Hanya mobil yang dapat diperbolehkan untuk melewati area ini.

\section{Area Drive-thru}

Pada rancangan ini area drive-thru digunakan sebagai area supermarket. Supermarket ini memiliki sifat instant dimana setiap pengunjung bisa berbelanja tanpa harus keluar dari mobilnya. Mobil dan motor diperbolehkan untuk melewati area ini.

\section{Area Pickup Point}

Pada rancangan area ini berfungsi untuk mengurangi populasi kendaraan pada bangunan. Area ini bersifat instant karena pay dan order menggunakan handphone. Area ini dapat dilalui oleh mobil dan motor.

\section{Analisis Sirkulasi}

Pengguna dalam bangunan ini dibagi 3 yaitu, pengguna motor. pengguna mobil, dan pejalan kaki.

Sirkulasi Mobil

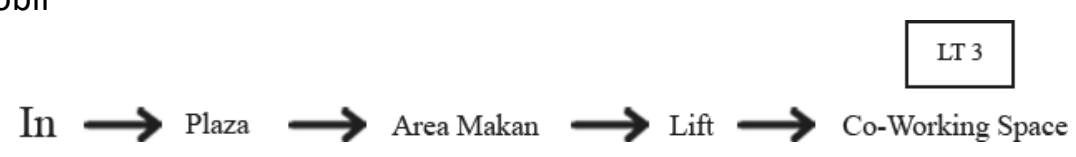

Gambar 7. Sirkulasi mobil Sumber: Penulis, 2020

Sirkulasi Motor
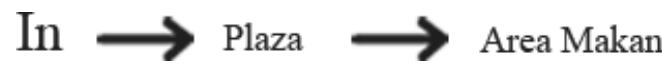
Area Order

Gambar 8. Sirkulasi motor Sumber: Penulis, 2020

Sirkulasi Pejalan Kaki

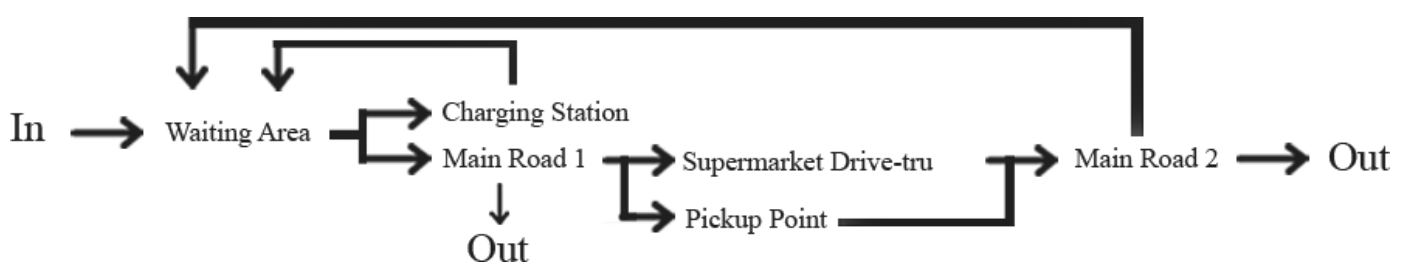

Gambar 9. Sirkulasi pejalan kaki dengan tujuan dine-in Sumber: Penulis, 2020

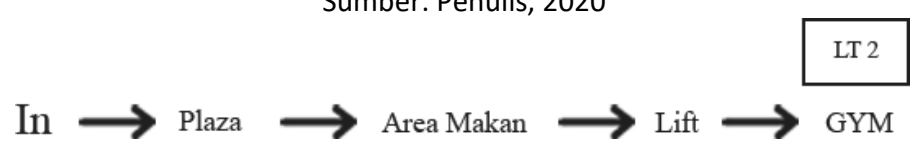

Gambar 10. Sirkulasi pejalan kaki dengan tujuan gym Sumber: Penulis, 2020 


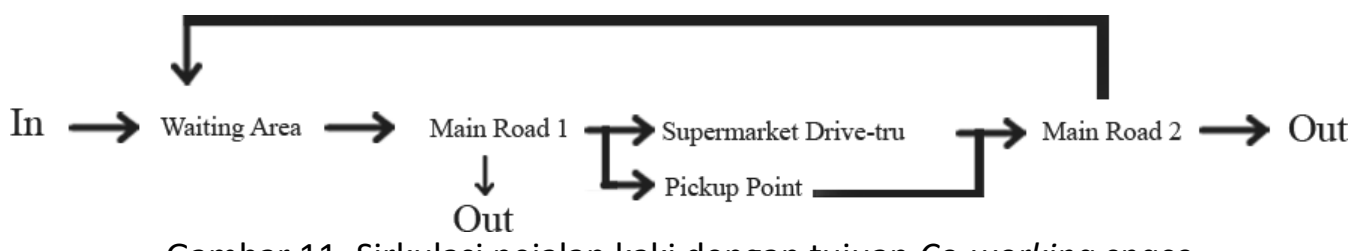

Gambar 11. Sirkulasi pejalan kaki dengan tujuan Co-working space Sumber: Penulis, 2020

\section{Analisis MEP}

Diagram Air Bersih

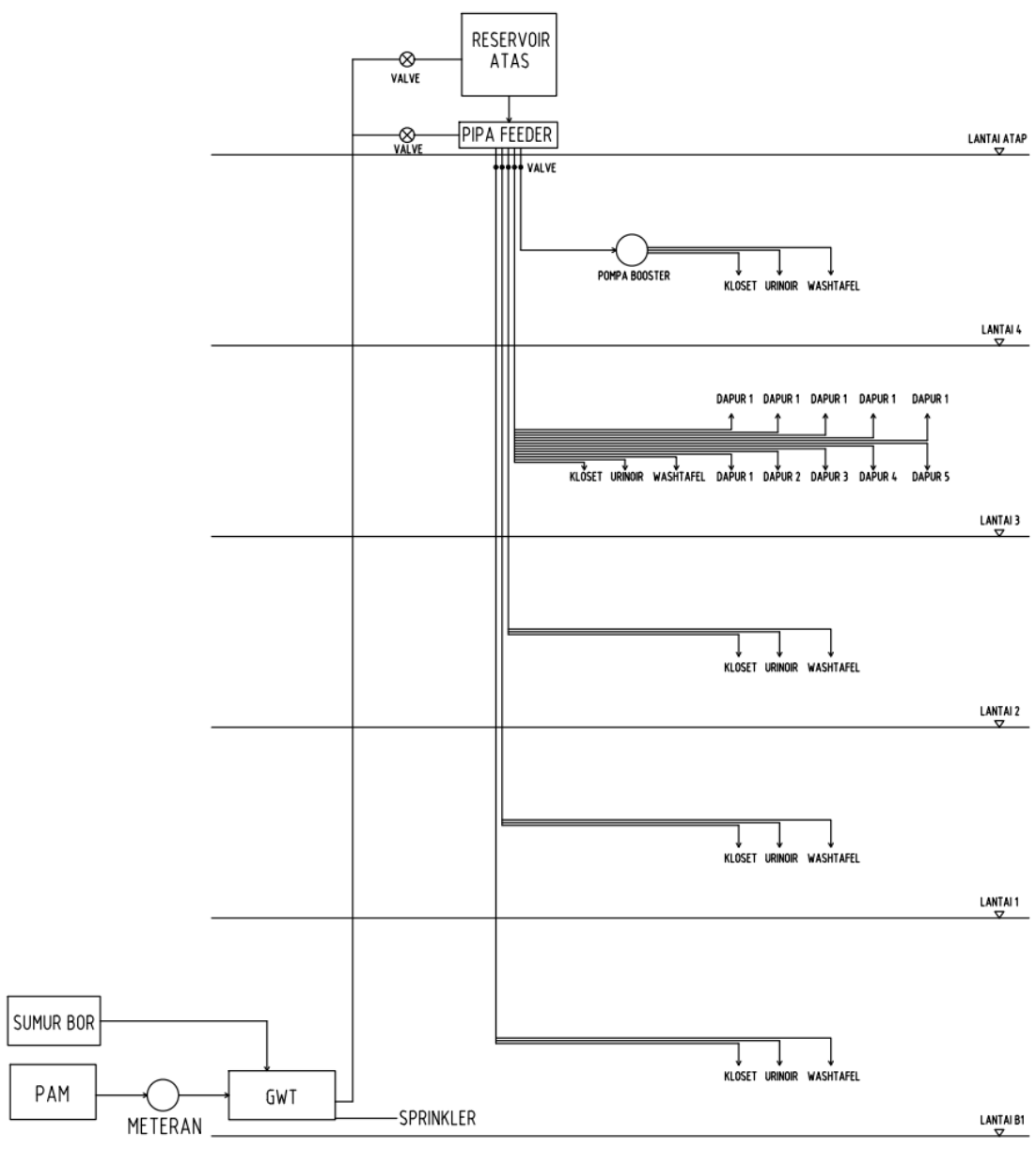

SINGLE LINE DIAGRAM AIR BERSIH

Gambar 12. Diagram air bersih Sumber: Penulis, 2020

Pada proyek menggunakan sumber air Pam dan air tanah dan dialirkan menuju toilet dan dapurdapur yang ada. 


\section{Diagram Air Kotor}

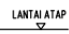

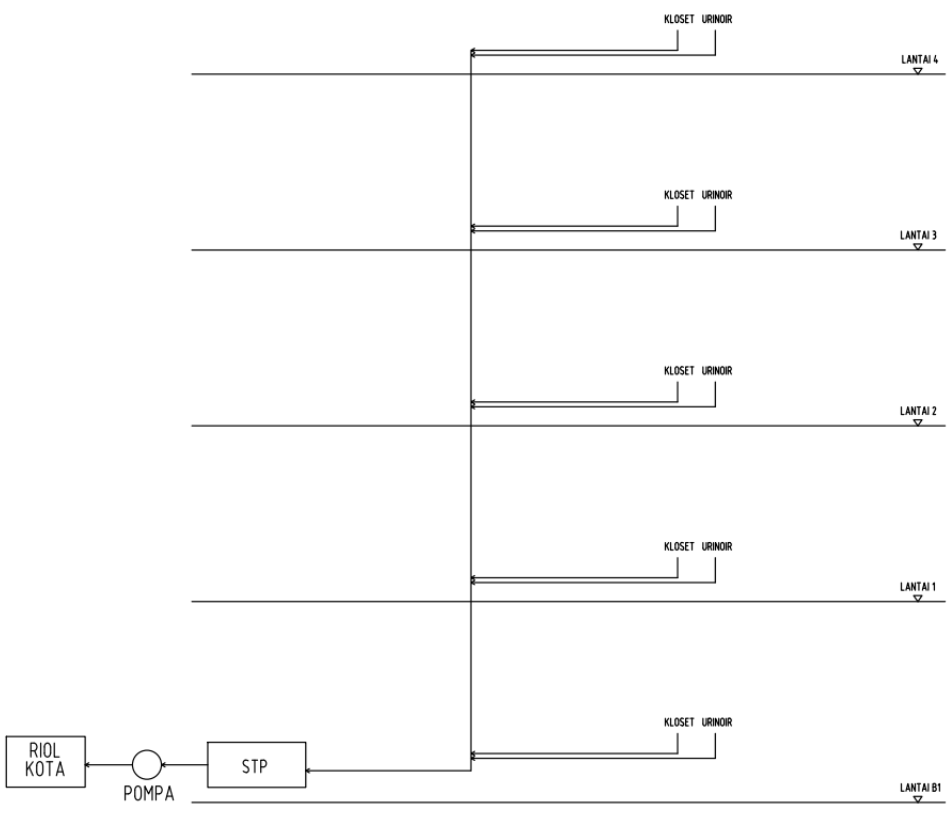

SINGLE LINE DIAGRAM AIR KOTOR

Gambar 13. Diagram air kotor

Sumber: Penulis, 2020

Diagram Air Bekas

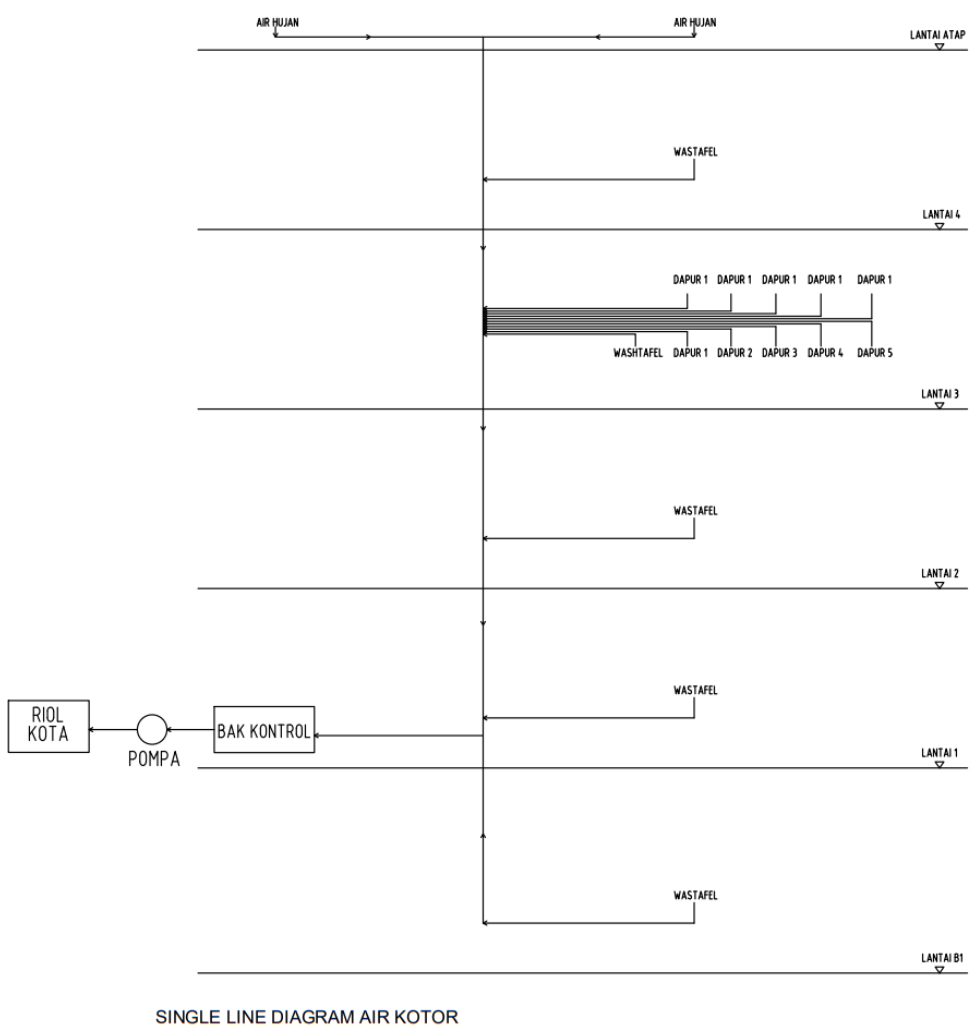

Gambar 14. Diagram air Bekas

Sumber: Penulis, 2020 


\section{Diagram Elektrikal}

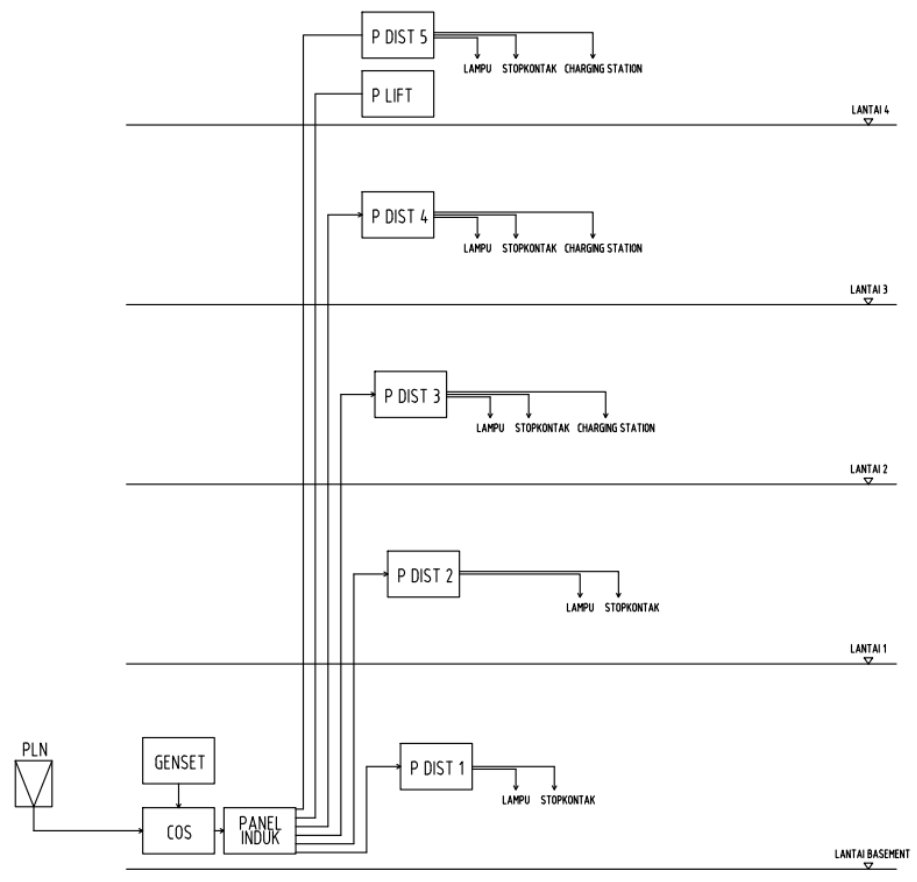

SINGLE LINE DIAGRAM ELECTRICAL DISTRIBUTION

Gambar 15. Diagram elektrikal

Sumber: Penulis, 2020

Diagram CCTV

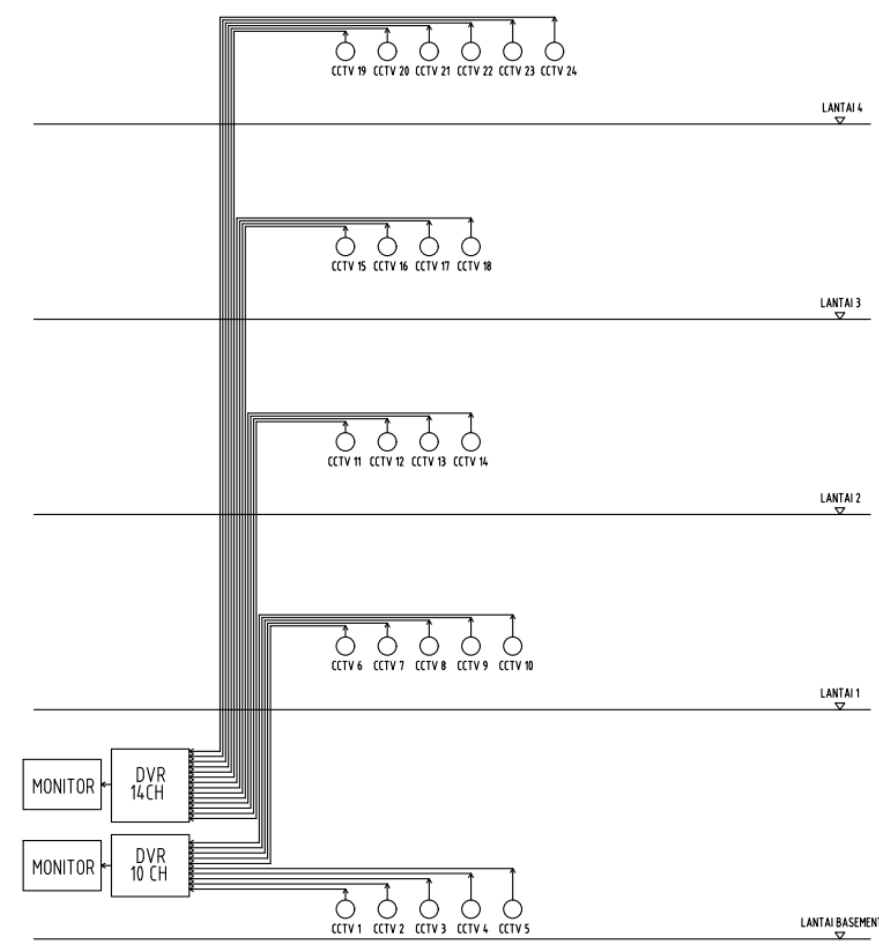

SINGLE LINE DIAGRAM CCTV

Gambar 16. Diagram CCTV

Sumber: Penulis, 2020 


\section{Diagram Telepon}

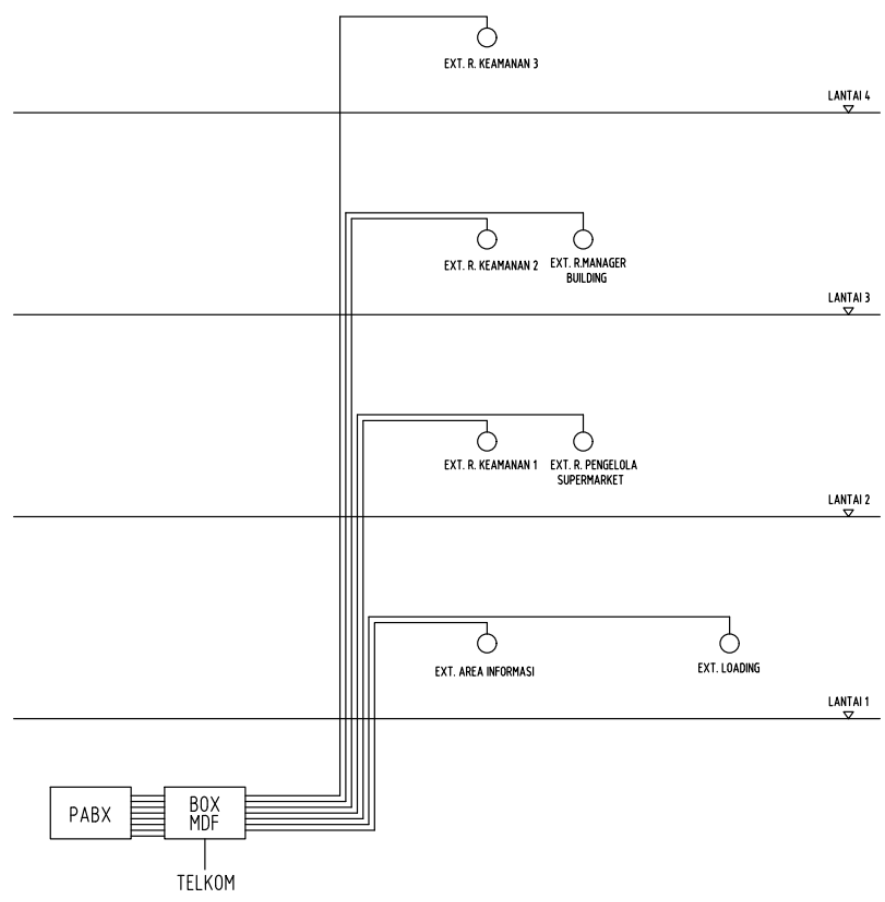

Gambar 17. Diagram telepon

Sumber: Penulis, 2020

\section{Analisis Bentuk}

Pada proses pembentukkan massa bangunan, bangunan utama menggunakan bentuk lingkaran dengan proses seperti berikut:

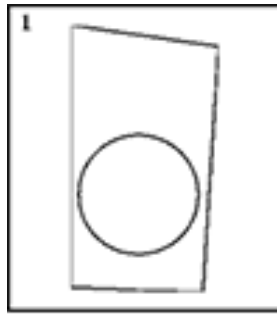

Bentuk Drive-in berupa Membuat extension lingkaran.

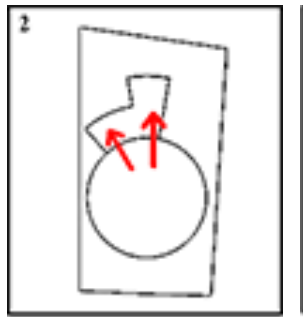

Sepanjang tapak

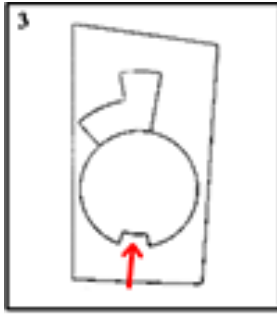

Membuat cekukan sebagai entrance

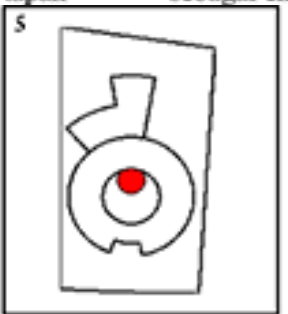

Sirkulasi vertikal di tengah void

Gambar 18. Proses Gubahan Massa

Sumber: Penulis, 2020

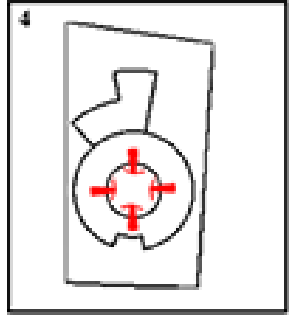

Membuat void ditengah massa 


\section{Analisis Konsep}

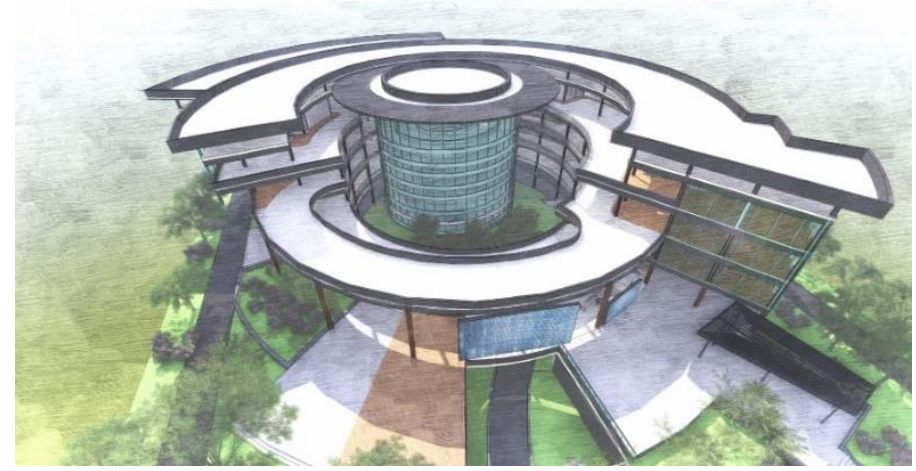

Gambar 19. 3D Bird View

Sumber: Penulis, 2020

Pada area drive-in bersifat semi outdoor dimana terdapat void pada tengah massa. Void tersebut ada untuk mengatasi masalah $\mathrm{Co} 2$ yang ada. Pada tengah void terdapat ramp lingkar yang digunakan sebagai sirkulasi vertikal.

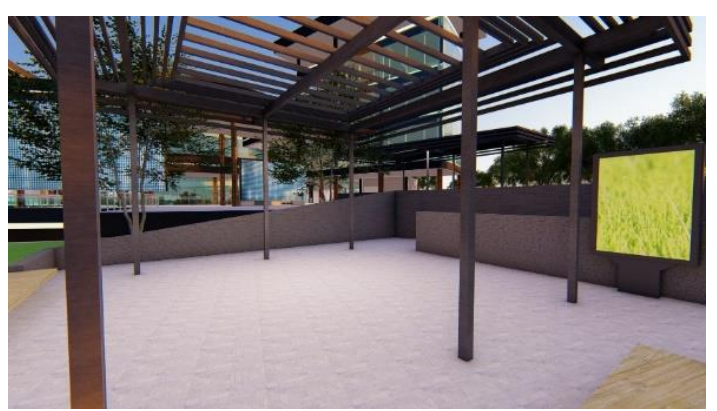

Gambar 20. 3D Halte Busway

Sumber: Penulis, 2020

Berikut area menunggu busway arah Serpong - Grogol. Dimana area menunggu disiapkan tempat duduk dan juga atap. Pada area menunggu juga disediakan advertisement screen dimana untuk menampilkan promo-promo yang sedang berlangsung. Target pengguna untuk halte adalah pejalan kaki.

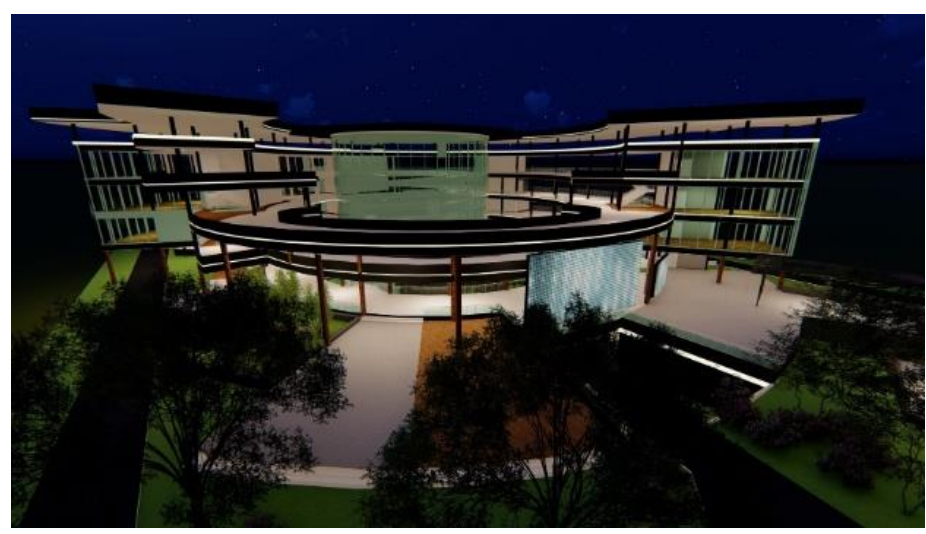

Gambar 21. 3D Nightview

Sumber: Penulis, 2020 
Pada tampak terdapat beberapa bagian yang glow in the dark. Dimana menggunakan cat Satiniq Luminos Acrylic Glow. Fasad menggunakan material tersebut untuk memperbaiki lingkungan yang gelap.

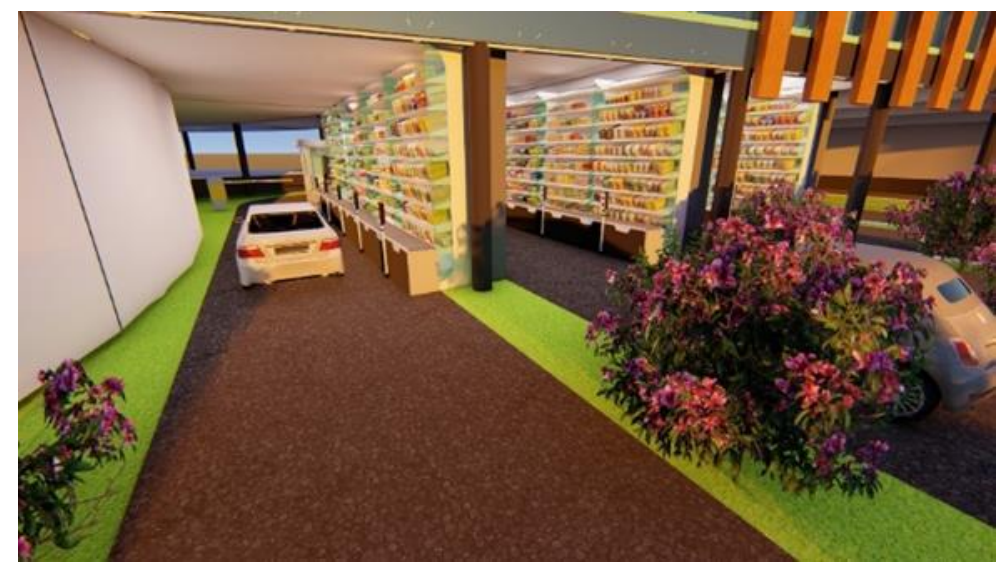

Gambar 22. 3D Perspektif Supermarket

Sumber: Penulis, 2020

Pada area drive-thru dibuat program supermarket dimana didalam terdapat lemari konveyer. Lemari tersebut berfungsi membawa barang menuju pengunjung. Didalam supermarket juga terdapat konveyer dimana berfungsi menghantarkan barang menuju kasir.

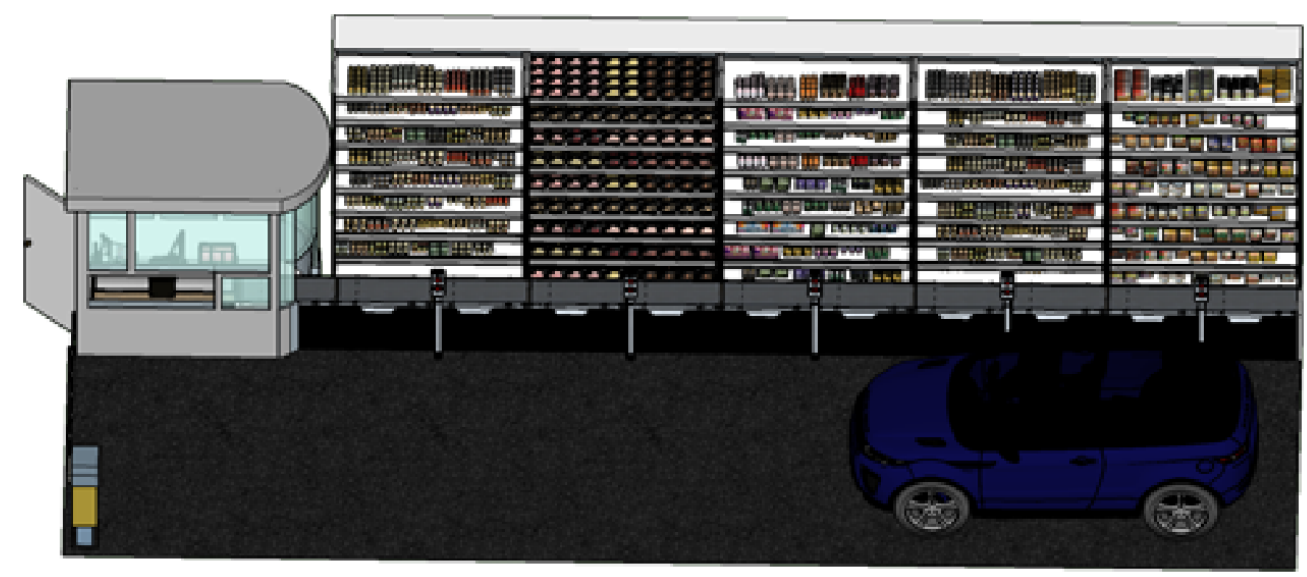

Gambar 23. Gambar Ilustrasi Supermarket Sumber: Penulis, 2020

\section{KESIMPULAN DAN SARAN \\ Kesimpulan}

Layanan Tanpa Turun Serpong ini dinilai dapat mengatasi masalah social distancing yang sedang terjadi. Tempat ini akan menjadi tempat untuk masyarakat masih dapat menjalankan kegiatan dwelling. Rancangan memberikan 2 hal utama yaitu dine-in dan drive-thru untuk memenuhi kebutuhan masyarakat. Tempat ini difokuskan untuk pengguna kendaraan bermotor seperti motor dan mobil. Dine-in menggunakan konsep charging+eat dimana charging station dijadikan sebagai anchor untuk menarik pengguna kendaraan listrik. Drive-thru supermarket menggunakan sistem dimana pengunjung tidak perlu turun dari kendaraan untuk berbelanja. Proyek ini memiliki visi untuk mempersiapkan program yang dapat mempertahankan lifestyle yang ada saat terjadinya social distancing maupun tidak. Proyek ini juga memiliki misi menciptakan ruang dengan konsep contactless technology and virtual prescense. Hal tersebut dapat terlihat dari program utama yang disediakan. 


\section{Saran}

Saran untuk pengembangan studi dan desain kelanjutannya yaitu sebagai berikut:

a. Penelitian yang dilakukan kemudian hari, perlu lebih banyak studi kasus mengenai sirkulasi drive-in dikarenakan adanya keterbatasan waktu dan perijinan untuk melakukan studi lapangan pada proyek sejenis tertentu.

b. Studi ini masih bisa dikembangkan lagi dalam hal sirkulasi barang dalam bangunan dan sirkulasi masuk dan keluar kendaraan.

\section{REFERENSI}

Arifin, F. P. A., and Harya S. S., Dillon. (2005). Pengalaman membangun Kota Baru: Bumi Serpong Damai. Pembangunan Kota Indonesia dalam Abad 21. Jakarta: Urban and Regional Development Institure (URDI) dan Yayasan Sugijanto Soegijoko

Heidegger, M. (1971). Building, Dwelling, Thinking. New York: Harper \& Row Publisher, Inc.

Macquarrie, John \& Robinso,Edward(Penerjemah)(1962). Martin Heidegger: Being And Time. German: British Library Cataloguing,h.99.

Sharr, Adam(Ed.).(2007) Heidegger For Architecture: United Stated : Taylor \& Francis eLibrary,h.12.

Shidfar, S. (2013). The Difference Between Dwelling and Home in Architecture. IJCSI International Journal of Computer Science Issues. 10(2). 239-243. https://ijcsi.org/papers/IJCSI-10-4-2-239-243.pdf

https://kecpamulang.tanggerangselatankota.go.id/

https://www.archdaily.com/ 
